recurrent fevers from the Eurofever registry. Orphanet Journal of Rare Diseases. 2017;12(1):16.

[3] Papa R, Lachmann HJ. Secondary, AA, Amyloidosis. Rheum Dis Clin North Am. 2018;44(4):585-603.

Acknowledgement: The presenting author would like to thank the European Federation of Immunology (EFIS) for the short term fellowship bursary.

Disclosure of Interests: Riccardo Papa: None declared, Thirusha Lane: None declared, Taryn Youngstein: None declared, Tamer Rezk: None declared, Charalampia Papadopoulou: None declared, Nicolino Ruperto Grant/research support from: The Gaslini Hospital, where NR works as full-time public employee, has received contributions (> 10.000 USD each) from the following industries in the last 3 years: BMS, Eli-Lilly, GlaxoSmithKline, F Hoffmann-La Roche, Janssen, Novartis, Pfizer, Sobi. This funding has been reinvested for the research activities of the hospital in a fully independent manner, without any commitment with third parties., Consultant for: Received honoraria for consultancies or speaker bureaus ( $<10.000$ USD each) from the following pharmaceutical companies in the past 3 years: Ablynx, AbbVie, Astrazeneca-Medimmune, Biogen, Boehringer, Bristol-Myers Squibb, Eli-Lilly, EMD Serono, GlaxoSmithKline, Hoffmann-La Roche, Janssen, Merck, Novartis, Pfizer, RPharma, SanofiServier, Sinergie, Sobi and Takeda., Speakers bureau: Received honoraria for consultancies or speaker bureaus $(<10.000$ USD each) from the following pharmaceutical companies in the past 3 years: Ablynx, AbbVie, Astrazeneca-Medimmune, Biogen, Boehringer, BristolMyers Squibb, Eli-Lilly, EMD Serono, GlaxoSmithKline, Hoffmann-La Roche, Janssen, Merck, Novartis, Pfizer, R-Pharma, SanofiServier, Sinergie, Sobi and Takeda., Paul Brogan Grant/research support from: SOBI, Novartis, Roche, Novimmune, Chemocentryx, Consultant for: Roche, SOBI, Speakers bureau: SOBI, Roche, Novartis, UCB, Philip N Hawkins: None declared, Patricia Woo: None declared, Marco Gattorno Grant/research support from: MG has received unrestricted grants from Sobi and Novartis, Helen J. Lachmann Grant/research support from: SOBI, Novartis, Consultant for: Novartis, Takeda, Speakers bureau: SOBI. Novartis DOI: 10.1136/annrheumdis-2019-eular.2502

\section{FRI0538 MAY SOME OF THE MEFV GENE VARIANTS CAUSE PFAPA SYNDROME LIKE SYMPTOMS?}

Mehmet Yildiz, Amra Adrovic, Ipek Ulkersoy, Neslihan Gucuyener, Oya Koker, Sezgin Sahin, Kenan Barut, Ozgur Kasapcopur. Cerrahpasa Medical School, Istanbul University Cerrahpasa, Department of Pediatric Rheumatology, Istanbul, Turkey

Background: PFAPA syndrome is characterized by periodic fever, aphthous stomatitis, pharyngitis and cervical adenitis. As diagnosis usually depends on clinical diagnostic criteria, sometimes it can be difficult to distinguish this clinical entity from the other periodic fever syndromes, especially in regions endemic for FMF.

Objectives: The objective of the study is to evaluate the PFAPA patients' MEFV gene variation frequencies (if it was performed) and relations between detected variants and clinical manifestations in pediatric PFAPA patients.

Methods: Nine hundred and thirty-seven patients that were recorded to our database as PFAPA syndrome were evaluated. Patients were reached by phone and asked about characteristics of their fever episodes, presence of acute phase reactant elevation, pharyngitis, aphthous stomatitis/cryptic tonsillitis, cervical lymphadenopathy, arthralgia, arthritis, abdominal pain, headache, nausea or vomiting, chest pain, diarrhea, skin changes, myalgia and conjunctivitis in the course of fever attack, if they had tonsillectomy, if they were attack-free after tonsillectomy and if they had clinical response to steroid or colchicine.

Results: There were 937 PFAPA patients in our database. MEFV gene analysis was performed in 407 (\%43) of PFAPA patients and 305 of them had at least one mutation. Most common MEFV mutations of patients were: R202Q heterozygotes (25,9\%), M694V heterozygotes $(24,2 \%)$, E148Q heterozygotes $(13,4 \%)$, P369S heterozygotes $(9,8 \%)$ and V726A heterozygotes (8,6\%), respectively. $\% 45.8$ of detected mutations were located in exon 2,\%40,3 of them were located in exon 10 and\% 13,9 of them were located in exon 3 of the MEFV gene. Patients were divided into five groups according to their mutations' localization and groups were compared according to clinical features. There were significant differences between groups according to presence of pharyngitis, arthralgia, abdominal pain, myalgia and tonsillectomy history (Table 1).
Table 1. Comparison of patients according to their mutations' location and clinical features.

\begin{tabular}{|c|c|c|c|c|c|c|c|}
\hline & & Exon 2 & Exon 3 & $\begin{array}{c}\text { Exon } \\
10\end{array}$ & $\begin{array}{c}\text { No } \\
\text { Mutation }\end{array}$ & $\begin{array}{c}\text { MEFV study } \\
\text { not } \\
\text { performed }\end{array}$ & $p$ \\
\hline Pharyngitis & $\begin{array}{l}\text { Yes } \\
\text { No }\end{array}$ & $\begin{array}{c}21 \\
(87,5) \\
3(12,5)\end{array}$ & $\begin{array}{c}9(40,9) \\
13 \\
(59,1)\end{array}$ & $\begin{array}{c}45 \\
(80,4) \\
11 \\
(19,6)\end{array}$ & $\begin{array}{c}28(87,5) \\
4(12,5)\end{array}$ & $\begin{array}{l}168(87,5) \\
24(12,5)\end{array}$ & $<0,05$ \\
\hline $\begin{array}{l}\text { Aphthous } \\
\text { stomatitis/Cryptic } \\
\text { tonsillitis }\end{array}$ & $\begin{array}{l}\text { Yes } \\
\text { No }\end{array}$ & $\begin{array}{c}15 \\
(62,5) \\
9(37,5)\end{array}$ & $\begin{array}{c}8(36,4) \\
14 \\
(63,6)\end{array}$ & $\begin{array}{c}21 \\
(37,5) \\
35 \\
(62,5)\end{array}$ & $\begin{array}{l}17(53,1) \\
15(46,9)\end{array}$ & $\begin{array}{c}102(53,1) \\
90(46,9)\end{array}$ & 0,11 \\
\hline $\begin{array}{l}\text { Cervical } \\
\text { lymphadenopathy }\end{array}$ & $\begin{array}{l}\text { Yes } \\
\text { No }\end{array}$ & $\begin{array}{c}10 \\
(41,7) \\
14 \\
(58,3)\end{array}$ & $\begin{array}{c}8(36,4) \\
14 \\
(63,6)\end{array}$ & $\begin{array}{c}21 \\
(37,5) \\
35 \\
(62,5)\end{array}$ & $\begin{array}{l}14(56,3) \\
18(43,7)\end{array}$ & $\begin{array}{c}77(40,1) \\
115(59,9)\end{array}$ & 0,97 \\
\hline Arthralgia & $\begin{array}{l}\text { Yes } \\
\text { No }\end{array}$ & $\begin{array}{c}5(20,8) \\
19 \\
(79,2)\end{array}$ & $\begin{array}{l}11(50) \\
11(50)\end{array}$ & $\begin{array}{c}22 \\
(39,3) \\
34 \\
(60,7)\end{array}$ & $\begin{array}{l}19(59,4) \\
13(40,6)\end{array}$ & $\begin{array}{c}66(34,5) \\
126(65,5)\end{array}$ & 0,02 \\
\hline Abdominal Pain & $\begin{array}{l}\text { Yes } \\
\text { No }\end{array}$ & $\begin{array}{c}17 \\
(70,8) \\
7(29,2)\end{array}$ & $\begin{array}{c}12 \\
(54,5) \\
10 \\
(45,5)\end{array}$ & $\begin{array}{c}27 \\
(48,2) \\
29 \\
(51,8)\end{array}$ & $\begin{array}{l}16(50) \\
16(50)\end{array}$ & $\begin{array}{c}56(70,8) \\
136(29,2)\end{array}$ & $<0,05$ \\
\hline Myalgia & $\begin{array}{l}\text { Yes } \\
\text { No }\end{array}$ & $\begin{array}{c}0(0) \\
24(100)\end{array}$ & $\begin{array}{c}8(36,4) \\
14 \\
(63,6)\end{array}$ & $\begin{array}{c}9(16,1) \\
47 \\
(83,9)\end{array}$ & $\begin{array}{c}7(21,9) \\
25(78,1)\end{array}$ & $\begin{array}{c}24(12,5) \\
168(87,5)\end{array}$ & 0,006 \\
\hline Tonsillectomy & $\begin{array}{l}\text { Yes } \\
\text { No }\end{array}$ & $\begin{array}{c}14 \\
(58,3) \\
10 \\
(41,7)\end{array}$ & $\begin{array}{c}5(22,7) \\
17 \\
(77,3)\end{array}$ & $\begin{array}{c}21 \\
(38,9) \\
33 \\
(66,1)\end{array}$ & $\begin{array}{l}20(62,5) \\
12(37,5)\end{array}$ & $\begin{array}{c}109(57,1) \\
82(42,9)\end{array}$ & 0,005 \\
\hline
\end{tabular}

Conclusion: In this study, we reported increased frequency of MEFV mutations in a large PFAPA patients cohort. Frequency differences of clinical features between groups suggest that some of the MEFV gene mutations may modify phenotype of PFAPA syndrome. Furthermore underlying MEFV gene mutations possibly lead to PFAPA like clinical pre sentation in FMF patients. Another remarkable finding of this study is the relatively high P369S mutation rates in patients with PFAPA syndrome.

\section{REFERENCES:}

[1] Pehlivan E, Adrovic A, Sahin S, et al. (2018). PFAPA Syndrome in a Population with Endemic Familial Mediterranean Fever. The Journal of pediatrics, 192, 253-255.

[2] Yamagami K, Nakamura T, Nakamura R, et al. (2017). Familial Mediterranean fever with $\mathrm{P} 369 \mathrm{~S} / \mathrm{R} 408 \mathrm{Q}$ exon3 variant in pyrin presenting as symptoms of PFAPA. Modern rheumatology, 27(2), 356-359.

Disclosure of Interests: None declared

DOI: 10.1136/annrheumdis-2019-eular.2258

\section{FRI0539 WNT6 MUTATION CAUSES AN EARLY ONSET GRANULOMATOSUS INTESTINAL DISEASE WITH RECURRENT HEMOPHAGOCYTIC LYMPHOHISTIOCYTOSIS (HLH)}

Claudia Bracaglia ${ }^{1}$, Daniela Knafelz ${ }^{2}$, Fiammetta Bracci $^{2}$, Antonella Insalaco $^{1}$, Giulia Marucci ${ }^{1}$, Manuela Pardeo ${ }^{1}$, Giusi Prencipe ${ }^{1}$, Ivan Caiello ${ }^{1}$,

Antonia Pascarella ${ }^{1}$, Marcello Niceta ${ }^{3}$, Francesca Pantaleoni ${ }^{3}$, Andrea Ciolfi ${ }^{3}$ Bronislava Papadatou ${ }^{2}$, Marco Tartaglia ${ }^{3}$, Giuliano Torre ${ }^{2}$, Fabrizio De Benedetti ${ }^{1}$. ${ }^{1}$ IRCCS Ospedale Pediatrico Bambino Gesù, Division of Rheumatology, Rome, Italy; ${ }^{2}$ IRCCS Ospedale Pediatrico Bambino Gesù, Hepatology, Gastroenterology and Nutrition Unit, Rome, Italy, ${ }^{3}$ IRCCS Ospedale Pediatrico Bambino Gesù, Genetics and Rare Diseases Research Division, Rome, Italy

Background: Use of NGS in patients with unclassifiable disease lies a possible approach to the identification of novel disease causing genes. Objectives: We report a patient with an early onset inflammatory bowel disease with granulomatous lesions and recurrent HLH episodes carrying a missense mutation in the WNT6 gene.

Methods: A trio based Whole Exome Sequencing (WES) approach was used. Cytokine levels were measured by multiplex assay and by specific ELISAs.

Results: Ten years old Caucasian boy affected by early onset pan-colitis from 9 months of age. Since the disease onset the patient is on glucocorticoid treatment with amino acidic enteral nutrition and oligo antigenic diet. Because of recurrent disease relapses at any attempt of glucocorticoid withdrawal, azathioprine and cyclosporine treatments were also added. At 2 years of age he received total colectomy with ileostomy. 
Because of insufficient disease control, treatment with a TNF-inhibitor (infliximab) was started with apparent improvement of intestinal symptoms. However, persistent granulomatous inflammatory disease of the distal portion of the ileus-rectal anastomosis persisted. Moreover, the patient presented recurrent $\mathrm{HLH}$ episodes that required high dose of glucocorticoid and cyclosporine-A treatment. Except one HLH episode related to a varicella zoster infection, the other HLH events were most likely triggered by his underlying inflammatory condition. During the HLH episodes levels of IL-18 were moderately elevated $(10.880 \mathrm{pg} / \mathrm{ml})$ the IFN-gamma induced chemokine CXCL9 was markedly high $(21.871 \mathrm{pg} / \mathrm{mL})$ and remained markedly elevated also during clinical and laboratory $\mathrm{HLH}$ remission (3.121 $\mathrm{pg} / \mathrm{ml}$ and $9.929 \mathrm{pg} / \mathrm{ml}$ respectively). Considering the early disease onset, primary immunodeficiency and early intestinal bowel disease onset were genetically ruled out as well as chronic granulomatosis diseases through extensive NGS panels. WES revealed carriage of a private (MAF: 1/125568, TOPMED), predicted pathogenic (CADD: 31), homozygous variant of WNT6 (c.793G $>$ C; p.(Asp265His); NM 006522.3). The patient is now partially controlled on low dose of oral glucocorticoid $(0.1$ $\mathrm{mg} / \mathrm{kg})$, cyclosporine-A $(5 \mathrm{mg} / \mathrm{kg})$ and antimicrobic treatment.

Conclusion: WNT signalling has been primarily described as a regulatory pathway in ontogeny and homeostatic processes. Schaale at al. demonstrated that WNT6 is expressed in granulomatous lesions in the lung of Mycobacterium tuberculosis-infected mice. Moreover, they found that the transcription factor c-Myc is significantly induced in murine macrophages by WNT6. This identifies WNT6 as a novel factor driving macrophage polarization toward an M2-like phenotype, suggesting a role for WNT6 in macrophage differentiation. Our case suggests defective function of WNT6 might be involved in the development of a granulomatous disease. WNT6 role in macrophage differentiation and polarization might also be important in the activation of the IFN-gamma pathway and in recurrent $\mathrm{HLH}$ episodes.

\section{REFERENCES:}

[1] K. Schaale, et al. Wnt6 Is Expressed in Granulomatous Lesions of Mycobacterium tuberculosis-Infected Mice and Is Involved in Macrophage Differentiation and Proliferation. J Immunol 2013; 191:5182-5195.

Disclosure of Interests: Claudia Bracaglia: None declared, Daniela Knafelz: None declared, Fiammetta Bracci: None declared, Antonella Insalaco: None declared, Giulia Marucci: None declared, Manuela Pardeo: None declared, Giusi Prencipe: None declared, Ivan Caiello: None declared, Antonia Pascarella: None declared, Marcello Niceta: None declared, Francesca Pantaleoni: None declared, Andrea Ciolfi: None declared, Bronislava Papadatou: None declared, Marco Tartaglia: None declared, Giuliano Torre: None declared, Fabrizio De Benedetti Grant/research support from: Abbvie, SOBI, Novimmune, Roche, Novartis, Sanofi, Pfizer DOI: 10.1136/annrheumdis-2019-eular.4687

\section{\begin{tabular}{l|l} 
FRI0540 & A NOVEL AUTOINFLAMMATORY DISEASE
\end{tabular} CHARACTERIZED BY NEONATAL-ONSET CYTOPENIA WITH AUTOINFLAMMATION, RASH, AND HEMOPHAGOCYTOSIS (NOCARH) DUE TO ABERRANT CDC42 FUNCTION}

Michael T. Lam ${ }^{1,2} 3$, Simona Coppola ${ }^{4}$, Oliver H. Krumbach ${ }^{5}$, Giusi Prencipe ${ }^{6}$, Antonella Insalaco $^{6}$, Cristina Cifaldi ${ }^{7,8}$, Immacolata Brigida $^{9}$, Serena Scala ${ }^{9}$, Marcello Niceta $^{10}$, Andrea Ciolfi ${ }^{10}$, Alexandre Carisey ${ }^{1,2}$, Mohammad Akbarzadeh ${ }^{5}$ Andrea Finocchi ${ }^{7,8}$, Franco Locatelli ${ }^{11}$, Caterina Cancrini ${ }^{7,8}$, Alessandro Aiuti ${ }^{9,12,13}$, Reza Ahmadian ${ }^{5}$, Jordan S. Orange ${ }^{2}$, Fabrizio De Benedetti ${ }^{6}$, Marco Tartaglia ${ }^{10}$. ${ }^{1}$ Baylor College of Medicine, Department of Pediatrics, Houston, United States of America; ${ }^{2}$ Columbia University, Irving Medical Center, Department of Pediatrics, Houston, United States of America; ${ }^{3}$ Translational Biology and Molecular Medicine Graduate Program and Medical Scientist,Baylor College of Medicine, Houston, United States of America; ${ }^{4}$ National Center for Rare Diseases, Istituto Superiore di Sanità, Rome, Italy; ${ }^{5}$ Institute of Biochemistry and Molecular Biology II,Medical Faculty of the Heinrich-Heine, Dusseldorf, Germany, ${ }^{6}$ Ospedale Pediatrico Bambino Gesù, IRCCS, Division of Rheumatology, Rome, Italy; ${ }^{7}$ Ospedale Pediatrico Bambino Gesù, IRCCS, Department of Pediatrics, Rome, Italy, ${ }^{8}$ University of Rome Tor Vergata, Department of Systems Medicine, Rome, Italy; ${ }^{9}$ San Raffaele Telethon Institute for Gene Therapy (SR-TIGET),IRCCS San Raffaele Scientific Institute, Milan, Italy, ${ }^{10}$ Genetics and Rare Diseases Research Division, Ospedale Pediatrico Bambino Gesù, IRCCS, Rome, Italy; ${ }^{11}$ Ospedale Pediatrico Bambino Gesù, IRCCS, Department of Pediatric Hematology and Oncology, Rome, Italy, ${ }^{12}$ San Raffaele Scientific Institute, Pediatric Immunohematology, Milan, Italy, ${ }^{13}$ Vita Salute, San Raffaele University, Milan, Italy

Background: Despite continuous advances in the identification of novel causative genes, several patients with a clinical autoinflammatory phenotype remain unclassifiable
Objectives: to describe a novel hematological and autoinflammatory disorder in three unrelated patients caused by a de novo missense mutation of CDC42

Methods: Whole exome sequencing was used to identify the novel variant. The functional impact of altered CDC42 function on hematopoiesis and inflammation was assessed through patient peripheral blood and bone marrow analyses, protein behavior and immune and non-immune cell functioning through in vitro biochemical and functional assays and in vivo $C$. elegans modeling

Results: Patients shared the same de novo missense mutation of CDC42 (NM_001791, Chr1:22417990, c.556C>T, p.R186C). Disease features included neonatal-onset cytopenia with dyshematopoiesis, autoinflammation, rash, and hemophagocytosis (collectively termed NOCARH syndrome) (Table). An altered hematopoietic compartment (prevalence of early differentiation elements and substantially decreased clonogenic progenitors) was demonstrated. Complementary assays documented the unique consequences of this mutation on CDC42 localization and function, and its dis ruptive effect on cell behavior and developmental processes, possibly linked to actin dysregulation. Increased secretion of $\mathrm{IL}-1 \beta$, and particularly of IL-18, was observed via ex vivo spontaneous release from unstimu lated bone marrow mononuclear cells and by high levels in bone marrow supernatants and plasma. IFN $\gamma$ was also increased and correlated to CXCL9 levels which were strictly related to ferritin levels. Treatment with anakinra and emapalumab, a monoclonal antibody to ilFN $\gamma$, was identified as critical in the survival of one patient, who underwent successful hematopoietic stem cell transplantation

\begin{tabular}{|l|c|c|c|}
\hline & Patient 1 & Patient 2 & Patient 3 \\
\hline Outcome and status & Alive, 6 yrs & Dead, 6 mos & Dead, 1.5yrs \\
\hline Fever & + & + & + \\
\hline Skin rash & + & + & + \\
\hline $\begin{array}{l}\text { Hepato- } \\
\text { Splenomegaly }\end{array}$ & + & + & + \\
\hline $\begin{array}{l}\text { Hemophagocytic } \\
\text { lymphohistiocytosis }\end{array}$ & + & + & + \\
\hline $\begin{array}{l}\text { Gastrointestinal } \\
\text { symptoms }\end{array}$ & + & + & + \\
\hline Cytopenia & + & + & + \\
\hline $\begin{array}{l}\text { Acute phase } \\
\text { response }\end{array}$ & + & + & + \\
\hline $\begin{array}{l}\text { Bone marrow } \\
\text { dysplasia }\end{array}$ & + & + & + \\
\hline
\end{tabular}

Conclusion: The p.R186C amino acid substitution in CDC42 underlies a novel, unique syndrome where CDC42 functional dysregulation has pleiotropic effects, causing hematopoietic disturbance, hyperinflammation, and immune impairment. Early recognition and control of $\mathrm{HLH}$, through neutralization of IFN $\gamma$, followed by hematopoietic stem cell transplantion, appear to be crucial to survival.

Disclosure of Interests: Michael T. Lam: None declared, Simona Coppola: None declared, Oliver H. Krumbach: None declared, Giusi Prencipe: None declared, Antonella Insalaco: None declared, Cristina cifaldi: None declared, Immacolata Brigida: None declared, Serena Scala: None declared, Marcello Niceta: None declared, Andrea Ciolfi: None declared, alexandre carisey: None declared, Mohammad Akbarzadeh: None declared, Andrea Finocchi: None declared, Franco Locatelli: None declared, Caterina Cancrini: None declared, Alessandro Aiuti: None declared, Reza Ahmadian: None declared, Jordan S. Orange: None declared, Fabrizio De Benedetti Grant/research support from: Abbvie, SOBI, Novimmune, Roche, Novartis, Sanofi, Pfizer, Marco Tartaglia: None declared

DOI: 10.1136/annrheumdis-2019-eular.5622 